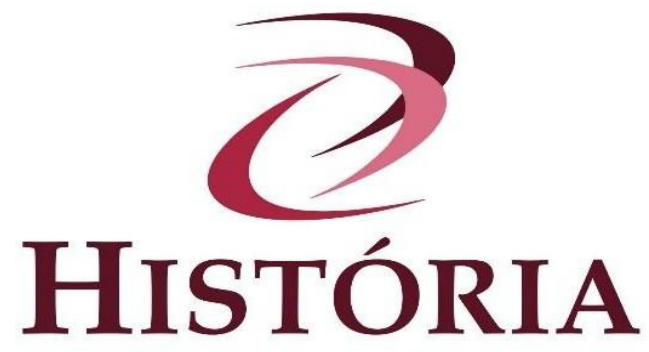

\title{
The Rockefeller Foundation and the League of Nations: Public Health in Europe (1920-1945)
}

\author{
A Fundação Rockefeller e a Liga das Nações: saúde pública na Europa (1920- \\ 1945)
}

\section{La Fundación Rockefeller y la Sociedad de Naciones: salud pública en Europa (1920-1945)}

\begin{abstract}
The Rockefeller Foundation (RF) and the League of Nations (LON) played a fundamental role in stabilization policies during the interwar period. Public health became essential in this context due to the immediate consequences of the war, the post-war economic crisis and the Great Depression. RF and LON became the cornerstone of international action in several fields: epidemics, famine, malnutrition, infectious diseases, infant mortality, drug abuse, biological and dietary standard-setting, epidemiological records, public health policies and professionalization. In the shaping international health expertise, LON and RF collaboration was extremely important, in terms of determining goals and programmes, and in terms of financial support. This article analyses the areas and the extent of their collaboration in Europe.
\end{abstract}

Keywords: Europe. International public health. Interwar years. League of Nations. Rockefeller Foundation.

Resumo: A Fundação Rockefeller (RF) e a Liga das Nações (LON) desempenharam um papel fundamental nas políticas de estabilização durante o período entre guerras. A saúde pública tornou-se essencial neste contexto devido às consequências imediatas da guerra, da crise económica do pós-guerra e da Grande Depressão. RF e LON tornaram-se a pedra angular da ação internacional em vários campos: epidemias, fome, desnutrição, doenças infecciosas, mortalidade infantil, abuso de drogas, estabelecimento de padrões biológicos e alimentares, registros epidemiológicos, políticas de saúde pública e profissionalização. $\mathrm{Na}$ formação da especialização internacional em saúde, a colaboração de LON e RF foi extremamente importante, em termos de determinação de objetivos e programas e em termos de apoio financeiro. Este artigo analisa as áreas e a extensão de sua colaboração na Europa.

Palavras-chave: Europa. Saúde pública internacional. Período entre guerras. Liga das Nações. Fundação Rockefeller.

Resumen: La Fundación Rockefeller (RF) y la Sociedad de Naciones (LON) jugaron un importante papel en las políticas de estabilización durante el período entreguerras. La salud pública era fundamental en este contexto histórico debido a las consecuencias inmediatas de la 
guerra, la crisis económica de la posguerra y la Gran Depresión. RF y LON se convirtieron en la piedra angular de la acción internacional en varios campos de la salud: epidemias, hambrunas, desnutrición, enfermedades infecciosas, mortalidad infantil, drogadicción, establecimiento de estándares biológicos y dietéticos, registros epidemiológicos, políticas de salud pública y profesionalización. En la formación de expertos en salud internacional, la colaboración entre LON y RF fue extremadamente importante para determinar metas y programas, y para el apoyo financiero. Este artículo analiza las áreas y el alcance de su colaboración en Europa.

Palabras clave: Europa. Salud pública internacional. Período entre guerras. Sociedad de Naciones. Fundación Rockefeller.

\section{Introduction}

The huge crisis caused by the Great War and the Great Depression radically transformed international relations (BOYCE, 2012). Health problems linked to the deterioration in living conditions figured prominently as authorities had to cope with the deep social crises affecting European countries in the first decades of the twentieth century. The challenge required a shift from the traditional public health control of plagues and infectious diseases based on preventive measures such as quarantining (SWAAN, 1988), to social medicine based on epidemiology and health statistics, vaccination and preventive campaigns, nutritional policies and bacteriological research (BOROWY; GRUNER, 2005). Empowered by state authorities which sought to implement social hygiene strategies, social medicine assessed the community's health condition and institutionalized a political and administrative apparatus to challenge social diseases that included venereal diseases but also mother and child health issues, alcoholism, mental disorders, and nutritional deficiencies (ANDRESEN, HUBBARD; RYYMIN, 2010). Social medicine was the institutionalized response of the liberal state to face the negative effects disease considered on its social dimension.

Several important features were involved in this paradigmatic shift, one of which was the changing role of international organizations as a new locus of expertise. The international context determined the orientation of medical research and the patterns of health policies, particularly in fields where international expert networks or committees appeared as technically legitimated bodies of knowledge and action. These experts represented national elites closely linked to health policies, which acquired growing scientific and political influence on public health care and health policies through national and international committees and networks. Moreover, health itself became a prominent social and political category during the pre-war years, inter-war and post-war years, at a time when the state emerged as a dominant social regulator that acted in most liberal societies to palliate the negative effects of so-called market failures and social inequalities and mitigate the threat of social conflicts (SWAAN, 1988, p. 1015). The growing influence of international networks and organizations on national health 
policies heightened the relevance of diplomatic debates and negotiations on implementing disease prevention and health care strategies.

Some historians have considered the role of international social medicine agencies such as the Rockefeller Foundation (RF), the League of Nations Health Organization (LNHO), and the Red Cross as a strategy associated with Western colonialism, the search for economic profit and pure political power (CUETO, 1994; CURTI, 1963). A significant portion of this literature has considered contemporary American philanthropy as a key agent in the global spread of capitalism and imperialism (BROWN, 1979). The interests of colonial powers, big corporations and financial trusts, so the argument goes, took priority over those of the native populations affected, grounded on the uncriticised assumption the metropolis and the colony shared the same idea of development and that their respective interests were coincident (SMITH, 1990; WEINDLING, 1993; SEALANDER, 1997). However, although there is little question that Western philanthropy and medical activism were not free of political interests, most philanthropic institutions, particularly the RF, have been shown to improve living standards by promoting public health policies, modernising agriculture, stimulating scientific research and providing instruction-grant programmes for the benefit of local elites as principal agents of public health policies (VOGEL, 2006). Thus, as I hope to show below, the international philanthropic intervention during the first half of the century not only promoted capitalism and imperialism, but also expanded the commitment of political authorities to notions of public health, civil rights, welfare and progress (ROSENBERG, 1982; PETERSEN, STEWART, SØRENSEN, 2013).

However, the framing of technical expertise associated with state and international organizations operated not only to legitimize international intervention and influence on state policies (FRIEDMAN; MCGARVIE, 2003). Another key aspect of the shift to social medicine involved the growing reliance on experts as technical, independent authorities (BARONA, 2010, p. 31-48). Humanitarian actions and medical activism became a wide movement in Western countries at a time of deep crisis and social conflict (BERLINER, 1985; PAGE, VALONE, 2007). This proved to be a bone of contention in the US during the first decades of the twentieth century (BOILING, SMITH, 1982; BREMNER, 1988; ZUNZ, 2011). Some organisations such as the Red Cross viewed mercy as an essential value of the medical practice, above and beyond assessments of moral and political character. Yet several other medical humanitarian associations that emerged during the interwar period also saw great importance in participating in the struggle between democracy, fascism and socialism (WETHERBY, 2014). 
Recent historiography describes an intensive debate about the aims and impact of the American philanthropic movement, both domestically and internationally. I argue that public health campaigns, policies and experts as promoted by the RF cannot be reduced to the role of hidden agents of imperialist foreign policy at a time of conflict and debate between imperialism and internationalism in American politics. The health politics and social medicine promoted by the RF's International Health Board/Division (IHB/D) and the Health Committee of the League of the Nations contributed to the formulation of national health policies and bureaucracies in many countries (LÖWY, ZYLBERMAN, 2000; FARLEY, 2004). During the interwar years, agents educated at internationally leading public health and bacteriological research institutions exerted unprecedented technical and ideological influence which increased the state's involvement in health policies, subsequently inspiring the welfare state policies of the Cold War era.

\section{The Urgent Collaboration: Epidemic and Famine in Eastern Europe}

After the Great War many governments organised public health services for the implementation of active health policies, but one of the main grounds for their failure was the lack of technical expertise. They decided therefore to develop a strategy of diplomatic and financial cooperation with foreign health authorities and policy makers so that preventive and sanitary campaigns would be coordinated and successful. This strategy was mainly based on the creation of an international body of expertise endowed with technical legitimacy, operating uniformly and negotiating strategies through expert committees, technical reports and conferences, and supported by international powers and health organisations to become the key reference of health policies.

The first contacts between the LNHO and the RF were in 1920 through the RF's European office, immediately after the LNHO was established. In February, Wickliffe Rose, Head of the RF's European Office in Paris, sent a letter to George E. Vincent, President of the IHB, and enclosed a copy of a health scheme for the League of Nations. International consensus regarding the importance of public health experts and the necessity of international health policies quickly emerged. Previous public health programmes promoted by the RF in different countries to cope with infectious diseases and epidemics were based on the creation of expertise in statistical evidence, complemented by technical knowledge and practical training in the field (TOURNÈS, 2012). These experts would become the elite of the local health administration, and act as authoritative references to national health services and policies (RAJCHMAN, 1921). 
On 18 February 1922, Ludwik Rajchman, a Polish bacteriologist, Medical Director of the LNHO, sent a long report to Wickliffe Rose analysing the serious risk represented by the typhus epidemic in Eastern European countries weakened by migrations and famine (RAJCHMAN, 1922). The Polish government officially applied for the immediate convocation of a European conference in Warsaw to consider the situation, prevent the infection from spreading westwards and create a "sanitary belt" on both sides of the frontiers between Russia and Ukraine and between Poland and Rumania. The conference was attended by technical representatives of twenty European governments; the US Public Health Service was also represented. Rajchman looked for “...general agreement for the establishment of this sanitary belt. In our mind it should consist of concentric lines, epidemic hospitals, quarantine and feeding stations, public bath, and delousing establishments, etc. on both sides of the frontier to a depth of some $150 \mathrm{~km} "$ (RAJCHMAN, 1922a, p. 2).

This strategy was to be implemented by state governments, but they were unable to do it with their own resources and Rajchman was afraid that epidemics would get out of control. He proposed taking the Rockefeller Foundation to the conference to get in contact with European representatives and launch a permanent organizing effort (RAJCHMAN, 1922b). Since then, the collaboration with the RF was a constant feature in epidemic campaigns and the fight against malaria, trachoma and other diseases. The consolidation of the LNHO accelerated the international health policies and boosted the RF's influence over public health politics.

International diplomacy became an essential tool not only for political stabilisation but also for negotiating solutions for transnational health problems. The expansion of national systems of social and health insurance drew attention to the social and economic burden represented by avoidable diseases. Once the LNHO came to be recognised as an essential agent for the League's stabilisation policies, it articulated an international timeline to eliminate diseases considered to be avoidable or preventable (TEN YEARS, 1930, p. 257). A report published after one decade of public health activity stated that:

In all its undertakings, the Health Organisation has fully observed the principle of cooperation
between all nations, as laid down in the Covenant of the League. Its work responds to the
universal need for the prevention of disease, which is felt more or less acutely in all countries
and in all continents. It has extended its activities to all parts of the world - to the Far East and
to America, to Africa and to Europe - and the results obtained during the past ten years are of
good augury for the future (TEN YEARS, 1930, p. 260).

At any time, governments could request the LNHO to place experts at their disposal to carry out specific tasks, produce technical reports, inform or advise on specific issues (REPORT, 1924). Expert opinions were often requested for specific campaigns against malaria, venereal diseases, dengue fever, and other diseases. Greece, Bolivia, China, Poland, Spain, 
among others, requested technical advice at various times and on different issues (BARONA, BERNABEU-MESTRE, 2008).

The international context brought the strategies and objectives of the LON and RF closer together, as show the following words by RF leader George Strode: "There are certain health functions that are essentially international in character; national governments cannot undertake them; they are important for the health of the people of all lands. The League is the first agency to be created that can undertake them. We should like therefore to see the Health Organization of the League succeed..." (STRODE, 1928).

In April 1922 Rajchman submitted to the RF his report on the Warsaw Conference. Conventions on quarantines and sanitary arrangements were approved and the implementation of the resolutions was left to the League's Epidemic Commission established in June 1920 following the growing awareness of the international dimension of post-war epidemics (ZINSSER, 1923, p. 2). One of the most relevant collaborative programmes, the Epidemiological Intelligence Service funded by the RF, was proposed at this conference (BARONA, 2015, p. 81-90).

The commission coordinated inter-governmental efforts to overcome the epidemic threat helping public health services in Eastern Europe. The commission consisted of Thorvald Madsen, Director of the Staten Serum Institut, Copenhagen, President of the League's Health Committee; George Buchanan, Senior Medical Officer at the British Ministry of Health, VicePresident of the Health Committee; Joseph Jitta, President of the Hygiene Council at the Low Countries; Ricardo Jorge, Director General of the Portuguese Public Health Administration; and Dr Violle, a member of the Pasteur Institute. All of them worked together to prepare a new International Sanitary Convention that would study existing quarantine arrangements and draft new agreements. Thus, a powerful international lobby was shaped to expand coordinated public health strategies and social medicine (ROSE, 1922).

\section{Public Health Experts and National Schools}

The RF and the League of Nations intervened in the instruction of public health experts, considering it essential for implementing health policies. This educational work was directly related to previous strategies implemented by the IHB of the RF. The central concept was that "hygiene is primarily a matter of education" (TEN YEARS, 1930, p. 242), and this applied not only to the citizens but also to national authorities and health officers. In order to improve international coordination, several lines of action were developed, including reports on the operations of health care services in different European countries. 
Meaningful social medicine work had been carried out during the turn of the $20^{\text {th }}$ century, but the emergence of the LNHO and its agreement with the RF represent a new and unprecedented impulse for the institutionalization of international collaboration. Among other things, the LNHO promoted exchanges by funding visits to study health care systems in other countries. The organisation of travelling exchanges was an initiative easily developed by the Secretariat of the League of Nations and the health authorities in different countries. The International Health Board of the Rockefeller Foundation assumed the programme and contributed with generous grants to those exchange visits, the first of them taking place in October 1922. In 1930, six hundred officers, not only of state members of the League of Nations, but also from other non-member countries, such as the United States of America, Mexico and the Soviet Union, took part in the exchange visits of sanitary staff. Among the visited nations were most of the European countries, Latin America, United States of America, Canada, Western Africa, India and Japan (LEAGUE OF NATIONS..., 1931).

The Interchange of Public Health Personnel programme aimed to bring public health administrators in different countries into closer relationship with each other, enabling comparative learning, evaluation and management of the organisation and legislation on public health. This strategy would contribute to an international perspective on health problems and greater spirit of collaboration. Convinced of its effectiveness, the RF agreed to pay an annual subvention to meet the programme's expenses, not to exceed 60,080 dollars a year for each of the three years from 1922 to 1925. Further agreements were made thereafter and the RF continued to support the programme by specific grants until 1931 (GRANT..., 1931).

The League soon learned to appreciate this opportunity to improve the information gathering, influence professional training and enhance the international experience of public health authorities and officers in as many countries as possible. The interchange was not designed for short-term observations, but for periods of definite service, establishing helpful contacts as a real exchange of experience on practical issues. One of the first decisions was to circulate reports about public health services in several European countries, with information on the administrative regulations, health legislation, social diseases, sanitary campaigns and key health problems, as well as the cooperation between private associations and health authorities. The International Health Yearbook published by the LON between 1925 and 1930 provided information about the progress made in each participating country, health care facilities, and new preventive measures.

Nevertheless, Rajchman was convinced that progress in international health could not be based exclusively on the exchange of information and laboratory research. To make the most 
of the exchange programme, the League proposed study tours - a quarterly one-month workshop convening fifty medical officers commissioned by governments to meet leading sanitarians. The aim of those study tours was to bring public health experts in touch with experts in other countries to promote international cooperation. The medical officers would then proceed to work within the ranks of another public health administration for a further eightweek period. Between 1922 and 1929, \$500,000 was allocated for the study tours (BOROWY, 2009, p. 192). At its Third Session in Paris, in May 1922, the League's Provisional Health Committee a resolution:

The Health Committee has taken note of the proposal regarding an interchange of sanitary personnel... and, in consideration of the great utility of ensuring that sanitary officers should become acquainted with practical solutions of public health problems as well as the organisation of public health services in various countries, recommends that the necessary steps should be taken by approaching the Governments interested in the matter in order to carry into effect this interchange at least as a provisional and experimental measure (RAJCHMAN, 1928, p. 2).

The first experimental interchange of experts took place in Belgium and Italy between October and December 1922 thanks to the grant provided by the RF. Since 1923 some activities were designed for public health officers, while others were related to specific issues such as policies and campaigns to fight tuberculosis, promote infant hygiene, introduce school hygiene, organise local and national health administration units such as port stations, and organise demographic and epidemiologic statistical services. In spite of the constant financial problems, the interchange was implemented year after year and was presented as one of the LNHO's most successful initiatives, creating a well-structured network of public health leaders, giving visibility and influence to both the League and the RF. As a matter of fact, the Conference of Malariologists (1924) gathered the most relevant international experts on malaria policies and research.

The interchange arranged from March to May 1925 involved major cities in the United States. The agenda included rural health, municipal sanitation, malaria research, industrial plants, education in public health, welfare institutions, health administration, the fight against typhoid fever and hookworm control, visits to the Johns Hopkins School of Public Health in Baltimore, sanitation, children's health, veterinary inspections and slaughter house management, quarantine stations, immigration examinations and health facilities. The study tour was mainly designed to involve Latin American leaders in public health intervention, mainly by implementing sanitation programmes. The Johns Hopkins School of Public Health in Baltimore, funded by the RF, served as training institution for foreign fellows. The political influence achieved through such meeting seems obvious, as the US was considered an authoritative reference in public health analysis and technologies for Latin American countries. 
Various types of collective interchanges were organised, the most common of which involved public health officers. Others focussed on particular issues, convening specialists such as health officers of maritime stations in the Mediterranean and Baltic, tuberculosis officers, sanitary engineers, medical school inspectors and others.

Malaria courses developed as an offshoot of this system of interchanges. Trained experts were needed in a number of countries and the League supported malaria courses at national health institutes in Hamburg, London and Paris, complemented by field training in Italy, Spain and Yugoslavia. The programme for 1926 included collective interchanges in Great Britain and Denmark (GUNN, 1925). The first were restricted to municipal health officers and visits were made to London institutions and the counties. An Interchange of Sanitary Engineers was held in London at the same time with the help of members of the Royal Sanitary Institute.

Next, Rajchman prepared a new model of interchange planned for July 1926 restricted to about ten participants from three or four neighbouring countries. The participants would be general health officers with special interests, and studies were to focus on special subjects relevant to two or three of the participating countries. These would be locally analysed, although the whole group would work together on problems of interest to all (GUNN, 1925). From 1922 to 1927 , collective interchanges were held in more than thirty territories worldwide: Algeria, Austria, Belgium, Canada, Cuba, Czechoslovakia, Dahomey, Danzig, Denmark, Egypt, France, Gambia, Germany, Gold Coast, Great Britain, Greece, French Guinea, Portuguese Guinea, Hungary, Italy, Ivory Coast, Japan, Korea, Latvia, Manchuria, Netherlands, Nigeria, Norway, Palestine, Poland, Senegal, Kingdom of the Serbs, Croats and Slovenes, Sierra Leone, Spain, Sudan, Sweden, Switzerland, Syria, Togoland and the United States (RAJCHMAN, 1928, p. 7). The participants in the activities were drawn from 52 countries, thirteen colonies or protectorates, and two mandated territories. In addition, 57 medical officers from thirty countries were selected to study pressing problems on an individual base. Experts from Asia were able to study how to prepare and administer anti-cholera vaccines in the countries and laboratories where these methods were developed. In addition, Japanese nutrition experts were given the opportunity to study advances in the science of nutrition in Western laboratories. According to League reports, by 1930, "six hundred officials... had participated in these interchanges of health personnel. Nearly all countries in Europe, as well as Latin America, the United States, Canada, West Africa, India and Japan, have been visited and have sent their officials to the study tours (TEN YEARS, 1930, p. 243).

In order to promote international cooperation in technical questions related to health problems, such as bacteriological, serological and epidemiological methods, vaccination 
standards, etc., two international courses for public health experts were organised in Paris and London in 1927. Medical officers from twenty different nationalities attended the courses, and then participated in a practical training tour in a several European countries. The interchange programme was maintained throughout the period of collaboration between the RF and the LNHO, creating a wide network of exchanges and interactions. Between 1923 and 1931 the RF and the LON organised 35 collective study interchanges in 31 countries involving 587 health officers from 61 countries and territories (TEN YEARS, 1930, p. 244).

When the interchange programme was re-evaluated in 1931 as usually all RF programmes were, one of its most appreciated achievements was having brought the health services of different countries into closer relationship with each other, facilitating comparative studies of national health organisations and legislations. Every interchange was followed by the publication of a handbook about the medical and health services of the visited country and the reports which the participants were requested to prepare were always comparative studies.

Following the strategy of building a strong international network of experts on public health policies, as early as January 1923 the Health Committee of the LON decided to survey programmes of specialisation in public health and preventive medicine in European, Japanese and American universities. On 20 February 1924, the committee appointed a permanent eightmember Commission on Education in Hygiene and Preventive Medicine, presided by French expert Léon Bernard. In 1930 the Dean of the Medical School in Shanghai joined the commission. Soon after its establishment, it decided to publish a comparative report on three main topics: (1) Training of experts, including medical officers, engineers, architects, nurses and public health staff; (2) Public health programmes for medical students and general practitioners; and (3) Public health programmes for social agents such as teachers, priests, and civil servants to contribute to public health education and the popularisation of hygiene standards.

The commission designed a project to extend and improve the instruction provided in medical centres, promoting programmes for experts in public health schools, as well as systems of evaluation, preparation of teaching materials for professionals, propaganda measures, popularisation programmes for teaching hygiene at school. The commission facilitated cooperation with national institutions for educating public health officers, nurses and auxiliary personnel in most European countries under the responsibility of national institutes of hygiene (ANNUAL REPORT..., 1926). Since the living conditions and health indicators in each country were the primary consideration, there was no question of a unique programme suitable for all institutes of hygiene, but it seemed a good idea to give the national institutes of health 
an opportunity to meet, exchange views and search for similar solutions.

Subsequently, a series of reports was issued about public health instruction in Austria, Finland, France, Germany, Hungary, Italy, the United States and Yugoslavia (SCHOOLS OF PUBLIC HEALTH, 1930). They were presented by the members of the commission, normally dealing with their own country or, in case of absence, advised by the information contributed by health officers of the several other countries. Additional reports by Tomasz Janiszewski showed the situation in Poland, Josephus Jitta reported the Low Countries and Nocht dealt with Germany. The general overview was complemented by other presentations on Belgium (Timbal), France (Léon Bernard), Switzerland and Italy (Giuseppe Ottolenghi), Great Britain (George Newman) and Germany (Carl Prausnitz) (BARONA, 2010). The vast amount of data collected by the committee informed a series of publications and international conferences to co-ordinate strategies in the instruction of experts and strategies in an international context. Obviously, decisions were not imposed over the states but negotiated under the League's and $\mathrm{RF}$ aegis. The objective was an international professional profile and a common instructive programme for health officers.

In 1926 the first International Conference for Directors of National Schools of Hygiene was held in Warsaw right after the Polish National School of Health had been inaugurated. In 1927 a second conference was held in Budapest and Zagreb on the occasion of the official opening of national schools in Hungary and Yugoslavia. The directors of the national schools in Prague, Warsaw, Rio de Janeiro, and São Paolo, as well as experts from health institutes in London, Berlin, Paris and Bologna, also took part in the meetings, together with representatives of the Rockefeller Foundation and Johns Hopkins School of Public Health.

The key issue on the agenda of those meetings was developing a curriculum for the instruction of public health experts. A complex discussion ensued around the need for experimental and non-experimental disciplines, the importance of statistical knowledge, the standardisation of research methods, and the required field training period. In addition, the state of teaching preventive medicine in the medical curriculum was compared among the different countries. Beyond public health education, arrangements were also made for technical cooperation on specific issues such as safe drinking water supply in rural districts, campaigns of oral vaccination against typhoid fever for children, prevention and treatment of scarlet fever and the fight against other infectious diseases (SCHOOLS OF PUBLIC HEALTH, 1930).

In 1928, an interchange of schools of public health for the study of rural hygiene led directly to the convening of a European Conference on Rural Hygiene by the League (BARONA, 2005). Rural health was a huge concern for national authorities. Demographic and 
epidemiologic records showed an evident urban-rural divide due to worse living conditions, difficult access to foodstuffs and lack of sanitation facilities in rural districts. This situation was drastically exacerbated during the Big Depression, leading to successive initiatives by governments worldwide for an international discussion about the best strategies to improve rural health. The conference recommendations constituted an agreement by the health authorities of European countries on a uniform standard of public health and health regulations in rural districts in the fields of medical care, health care organisation, drinking water supplies and sewage disposal, housing and land improvement.

The prospective action promoted by the League and funded by the RF helped to shape the professional profile of the public health expert and the role of health officers. While certain political parties and social movements tried to influence and modify the predominant statistical and technological orientation of social medicine by highlighting the importance of civil rights calling for more attention to women's health, housing, workers' health, birth control and similar issues, these initiatives had little effect on the predominant data-collection trend promoted by the RF. The RF was more concerned with teaching public health experts to promote a technical approach to the diagnosis and treatment of health problems, despite their awareness of their social dimension. In this collaborative strategy the RF contributed technical aid, grants, funds and an integrative international framework. Although the institutional autonomy and national sovereignty were always recognised and safeguarded, co-ordination with health authorities, universities and medical professionals was considered absolutely necessary and increasingly, the international context promoted by the LNHO and the RF put pressure on the national governments. The 1930 concluding report on common instruction programmes for public health experts included five main points (SCHOOLS OF PUBLIC HEALTH, 1930):

1. Public health schools were essential for the establishment of health policies and for the experts' instruction. Considered as technical institutions, they are to be independent from the administrative structure, political power and university models.

2. During the 1920s the Johns Hopkins School of Public Health, Harvard School of Public Health and others funded by the RF, as well as national schools in Madrid (1924), Warsaw (1925), Budapest, Zagreb (1926), London (1929), Prague (1930) and Athens (1930) followed this profile.

3. The aim of those institutions was to instruct public health experts in implementing health policies and popularising hygiene. They should associate research and teaching, offering practical training in laboratory technologies, research methods in 
social sciences, popularisation strategies, hygienic education and implementation of sanitary campaigns.

4. Research was an essential task not being divorced from the real health problems of the population.

5. An ambitious agreement to form a common European teaching programme to instruct medical health officers was proposed.

The national schools of public health were designed to monopolise knowledge and expertise, and to legitimate political action and social intervention. Health officers and inspectors were the key experts employed in training medical practitioners, public health assistants and other complementary staff, as well in advising on popularisation campaigns. Public health schools flourished in the 1920s and 1930s as crucial institutions to coordinate preventive campaigns, organise the fight against social diseases, implement new therapies and vaccination campaigns, and legitimize international public health expertise under the behest of the LNHO and RF. The policy of collaborative interaction and coordination between leaders of public health schools followed the same logic as the programme of interchange of public health officers.

Following the 1930 Paris conference and the welcome coincidence of the international agreement on public health teaching policies, the French government made a thoroughly detailed proposal for an international school of advanced health studies in Paris (BERNARD, 1930). The project was submitted to the Rockefeller Foundation after having been approved by the Council of the League of Nations. Before replying, the RF authorities requested the confidential opinion of several public health professors and experts, and also of Hampstead Laboratories and the Milbank Memorial Fund. Their response was unanimously positive. The political process started when the LON Council passed the proposal on 24 September 1930, and the Health Section drew a draft informed by Léon Bernard, stating the French government's commitment to establish the school with the support of the RF. Nevertheless, seven years later, in 1937, the project was still not implemented. The parliamentary debate in France was not as easy as it had been at the international agencies, and the French Senate failed to commit the required funds. On 7 April 1938 the Senate's Financial Committee finally rejected the detailed plan, and the ambitious project was never realised. 


\section{The International Epidemiological Intelligence Service and the Centre for Public Health Documentation}

Any scheme to secure the cooperation of national health administrations was dependent on the creation of an International Epidemiological Intelligence Service (IEIS) associated with a new Department of Public Health Statistics. Indeed, on 23 May 1922, the RF approved the IEIS plan proposed by the LON. Between 1922 and 1927 the RF donated \$350,000 to the LON for the institutionalization of vital statistics and epidemiological studies. However, the position of the British representative, George Buchanan, was critical in several senses. Buchanan claimed that a separate fund distinct from the budget of the League, administrated apart and named "Rockefeller Fund" should be created. He insisted that these funds were auxiliary and not part of the normal technical work. Regarding the IEIS, he proposed a broader project under the direction of the LON and the Office Internationale d'Hygiene Publique (BUCHANAN, 1922).

Notwithstanding British distrust, the agreement was approved by November 1922, and Selskar M. Gunn, head of the RF in Paris, issued a copy of the "Memorandum of the Medical Director to the Members of the Health Committee" which focused mainly on the establishment of the of the IEIS. Previously, in meetings held in May and October, and subsequent meetings of the Executive Committee, the RF had discussed and approved a plan of cooperation with the LON in establishing the service.

Once the IEIS was approved, Rajchman requested the RF support in appointing a leader to implement the service. "If we are to establish our Epidemiological Intelligence Service on a really firm basis, and if you help us in this direction, we shall require the services of a firstclass epidemiologist and Public Health Statistician" (RAJCHMAN, 1922b). Edgar Sydenstricker, an expert from the US Public Health Services, was appointed to organize and direct the Service for a minimum of two years.

In July 1923, the first Bulletin Mensuel de Renseignements Épidémiologiques was published. The IEIS provided updated and useful information for national health administrators. Based on these monthly bulletins, the first Rapport Épidémiologique Annuel was published in 1923. Statistical information required technical standardization for it to be comparable. Between 1923 and 1925 several committees comprised of the heads of the epidemiological services in Europe convened to compile a global report. Rajchman publicly supported this idea, but the initiative was seen as a foreign intrusion and was rejected by Buchanan. Despite the availability of reliably comparable records in different countries, Buchanan mistrusted the 
experts' internationalist perspective and their wish to influence state policies and domestic affairs, and Great Britain turned down the initiative of a series of international health yearbooks.

Despite the initial controversy, an International Health Yearbook was published in 1925 with the collaboration of 22 countries. Rajchman sent a letter to national authorities requesting updated reports on demographic and epidemiologic records, sanitary reforms, public health policies and social diseases. The yearbooks were published for six years, from 1925 to 1930, and included valuable records on by the International Labour Organization, International Red Cross, and RF. Thirty-seven countries participated in 1929 yearbook. Deficiencies in technical coordination and methodological and linguistic standardization made the results heterogeneous. After the 1929 crisis, the situation worsened and funds from the RF shrank. The 1930 issue was the last one published.

The International Health Yearbooks summarized and compiled national reports without any comparative transnational analysis. Reports offered demographic and epidemiologic information about institutions, facilities, sanitary staff, health care, medical insurances and other public health issues. One of their main contributions was the establishment of a framework of international information that was available to national governments and public health experts in their planning of health policies. This reinforced the demand of national offices for vital statistics as a decision-making tool.

Soon after its approval, the IEIS' mandate was extended. In 1922, the growing importance of this service led to a request by the Japanese representative for a survey of the epidemiological situation in the Far East, and the eventual establishment a regional coordinating mechanism similar to the one operating in Geneva (EPIDEMIOLOGICAL, 1925). The Japanese initiative was presented to the League's Health Committee. The Asian Office was located in Singapore. In December 1924, the LNHO and the RF began collaborating in the establishment and maintenance of an Epidemiological Intelligence Bureau in the Far East. After a couple of years the IEIS, as developed by Sydenstricker, was already fairly well established.

In addition to the previously mentioned programmes, a proposal for cooperation between the RF and the League in the establishment of a centre for the collection of public health documentation was presented in May 1927. Its main target was to collect and disseminate global documentation on public health activities: administrative reports, legal enactments, minutes of conferences, etc. Alfred Grotjahn, Professor of Social Hygiene at the University of Berlin and one of the most prominent specialists in social medicine, was requested by the LON to act as technical adviser. He accepted, and in March 1928 it was agreed to combine pledges for the IEIS and the establishment of the Centre for Public Health Documentation. In 1927 the 
RF had donated an initial amount of $\$ 7,000$ for the Centre, followed in $1930-1934$ by $\$ 700,000$, and $\$ 2 \mathrm{~m}$ more to fund a library and a centre of documentation of public health at the League headquarters in Geneva.

\section{Final Comments}

When the Health Organization of the League of Nations was established in 1921 general doubt prevailed as to what extent it would be possible to justify its existence, and whether it would win the support of national public health services. Financial support was essential for its continuity, but at this initial stage the political support was the most decisive factor. After the first campaigns to fight epidemics in Poland and Russia, and later on, when the first results were achieved, particularly the standardization of biological products, the creation of the Interchange of Public Health Officers and the IEIS, the Health Committee was encouraged to take the lead and expand the programmes. The support of the Rockefeller Foundation was an essential factor in implementing the large-scale public health programmes of the LON during the interwar period.

After 1926 national governments began to apply to the League for recommendations and technical help, for the creation of special commissions or for the study of public health problems. The strategy followed by the Medical Director of the LON Health Organization, Ludwik Rajchman, consisted of obtaining the collaboration of the RF and the best-qualified specialists employed in research institutions and national health bodies.

The RF financial support was essential not only in order to ensure the continuity of LON Health Organization activities, but also to maintain intact the technical staff responsible for the executive activities of international public health work. The strategy was clear: it was not to become engaged in directly promoting laboratory research or scientific discoveries, but its scope as an international public health organization was the practical application of the results of research advances consistently with the programmes of national health administrations. Obviously, the quality and the efficiency of both the schools of public health and the national institutes of hygiene in the instruction of public health experts and in national health policies were closely linked to the staff's high qualifications.

The political importance of public health and social medicine during the interwar years raises the question whether this system of specialised training in public health was the best and should persist in the future. The long collaboration between the RF's International Health Division and the LON was an essential instrument for the internationalization of public health, the establishment of permanent networks of international diplomacy around health and the 
deployment of a large network of public health experts, fully co-ordinated through conferences, institutional cooperation and political programmes. The technical approach to public health problems and the spirit of dialogue and negotiation were probably two of the greatest contributions to the expansion of international health policies according to the pattern of social medicine based mainly in epidemiology and health statistics, standardization of methods and values and experimental research. That was the core of the collaboration between the Rockefeller Foundation and the League of Nations - an outstanding chapter in the history of public health and a milestone in the process of turning health into a key agenda and powerful element in international diplomacy.

\section{References}

ANDRESEN, A.; HUBBARD, W. H.; RYYMIN, T. (Eds.). International and local approaches to health and health care. Oslo: Novus Press, 2010.

ANNUAL REPORT of the Health Organisation for 1925. Geneva, League of Nations Health Organisation, C.H. 442, 1926.

BARONA, J. L. The European Conference of Rural Health (1930, 1931). En: BARONA, J. L.; CHERRY, S. (Eds.). Health and medicine in Rural Europe (1850-1945). Valencia: PUV, 2005.

BARONA, J. L. Public health experts and scientific authority: international and local approaches. En: ANDRESEN, A.; HUBBARD, W. H.; RYYMIN, T. (eds.). International and local approaches to Health and Health Care. Oslo: Novus Press, 2010. p. 31-48.

BARONA, J. L. The Rockefeller Foundation, public health and international diplomacy. London: Pickering \& Chatto, 2015.

BARONA, J. L.; BERNABEU-MESTRE, J. La salud y el estado: el movimiento sanitario internacional y la administración española (1851-1945). València: PUV, 2008.

BERLINER, H. S. A system of scientific medicine: philanthropic Foundations in the Flexner Era. New York \& London: Tavistock, 1985.

BERNARD, L. Report on behalf of the Sub-Committee appointed to examine the French Government Proposal for "The Creation of an International School of Advanced Health Studies at Paris”. RAC, RG 6.1, Series 1.1, Box 38, Folder 466, 1930.

BOILING, L. R.; SMITH, C. Private foreign aid: US philanthropy for relief and development. Boulder: Westview Press, 1982.

BOROWY, I.; GRUNER, W. D. (Eds.). Facing illness in troubled times: health in Europe in the Interwar Years, 1918-1939. Frankfurt am Main: Peter Lang, 2005. 
BOROWY, I. Coming to terms with world health: the League of Nations Health Organisation, 1921-1946. Frankfurt am Main: Peter Lang, 2009.

BOYCE, R. R. The Great Interwar crisis and the collapse of globalisation. Basingstoke: Palgrave Macmillan, 2012.

BREMNER, R. H. American philanthropy. Chicago: University of Chicago Press, 1988.

BROWN, E. R. Rockefeller medicine men: medicine and capitalism in America. Berkeley: University of California Press, 1979.

BUCHANAN, G. Letter to MADSEN, Torvald. RAC, RG 6.1, Series 1.1, Box 38, Folder 471. 27 July 1922.

CUETO, M. (Ed.). Missionaries of science: The Rockefeller Foundation and Latin America. Bloomington: Indiana University Press, 1994.

CURTI, M. American Philanthropy abroad. New Brunswick: Rutgers University Press, 1963.

EPIDEMIOLOGICAL Intelligence Bureau in the Far East. RAC, RG 1.1, Series 100, Box 20, Folder 170, 1925.

FARLEY, J. To cast out disease: a history of the International Health Division of the Rockefeller Foundation (1913-1951). Oxford: Oxford University Press, 2004.

FRIEDMAN, L. J.; MCGARVIE, M. D. (Eds.). Charity, philanthropy, and civility in American History. Cambridge: Cambridge University Press, 2003.

GRANT for the maintenance of a system of interchange of public health personnel on an international scale. RAC, RG1.1. Series 100, Box 21, Folder 175, 1930, p. 1.

GUNN, S. Letter to F.F. Russell. RAC, RG 1.1, Series 100, Box 20, Folder 169. 23 October 1925.

LEAGUE of Nations Health Organisation. Information Section. Geneva, 1931, p. 18.

LÖWY, I.; ZYLBERMAN, P. (Eds.). Introduction: Medicine as a social instrument: Rockefeller Foundation, 1913-45. Studies in the History and Philosophy of Biology and Biomedical Sciences, v. 31, n. 3, p. 365-379, 2000.

PAGE, B. B.; VALONE, D. A. (Eds.). Philanthropic Foundations and the globalization of scientific medicine and public health. Lanham, MD: University Press of America, 2007.

PETERSEN, K.; STEWART, J.; SØRENSEN, M. K. (Eds.). American Foundations and European Welfare States. Odense: University Press of Southern Denmark, 2013.

RAJCHMAN, L. W. The League of Nations Health Organisation: what it is and how it works? Rockefeller Archive Center. RG 1.1, Series 100, Box 20, Folder 165. 18 November 1921. 
RAJCHMAN, L. W. Report on the Epidemic Situation in Eastern Europe. Rockefeller Archive Center, RG 1.1, Series 100, Box 20, Folder 165. 18 February 1922a.

RAJCHMAN, L. to ROSE, Wicklife. RAC, RG 1.1, Series 100, Box 20, Folder 164, 1922b.

RAJCHMAN, L. Review of the experience of the Health Organisation of the League of Nations with the ystem of Interchange of Public Health Personnel. RAC, RG 1.1, Series 100, Box 20, Folder 172, 1928.

REPORT of the Health Committee to the Permanent Committee. League of Nations Archives, A.22,1924. III.

ROSE, W. Epidemic control in Europe, and the League. American Review of Reviews, v. 46, p. 2, 1922.

ROSENBERG, E. S. Spreading the American dream: American economic and cultural expansion, 1890-1945. New York: Hill \& Wang, 1982.

SCHOOLS OF PUBLIC HEALTH 1930. Subjects for teaching... Report from G. K. Strode to F. Russell. RAC, RG 1.1, Series 100, Box 21, Folder 175, 1930.

SEALANDER, J. Private wealth and public life: foundation philanthropy and the reshaping of American social policy from the progressive Era to the New Deal. Baltimore: Johns Hopkins University Press, 1997.

SMITH, B. H. More than altruism: the politics of private foreign aid. Princeton: Princeton University Press, 1990.

STRODE, G. K. Memorandum on the health organisation of the League of Nations and the relationship thereto of the International Health Division of the Rockefeller Foundation. RAC, RG 1.1., Series 100, Box 22, Folder 184, p. 5-6. 10 July 1928.

SWAAN, A. Care of the State: health care, education and welfare in Europe and the USA in the Modern Era. New York: Oxford University Press, 1988.

TEN YEARS of World Co-operation. Secretariat of the League of Nations. London: Hazell, Watson \& Viney, 1930.

TOURNÈS, L. La philanthropie américaine, la Société des Nations et la coproduction d'un ordre international (1919-1946). Relations Internationales, v. 151, p. 25-36, jul.-sep. 2012.

VOGEL, A. Who's making global civil society: philanthropy and US empire in world society. British Journal of Sociology, v. 57, n. 4, p. 636-65, 2006.

WEINDLING, P. Public health and political stabilisation: The Rockefeller Foundation in Central and Eastern Europe between the two world wars. Minerva, v. 31, p. 253-67, 1993.

WETHERBY, A. The medical activists: humanitarians, activists, and American Medical Relief to Spain and China, 1936-1949. Oxford: PhD Thesis, 2014. 
ZINSSER, H. Report on Journey to Russia as epidemic commissioner of Hygienic Section, League of Nations, from June $11^{\text {th }}$ to July $20^{\text {th }}$, 1923. RAC, RG 1.1, Series 100, Box 22, Folder 183, 1923.

ZUNZ, O. Philanthropy in America: a history. Princeton: Princeton University Press, 2011.

Recebido: 19/06/2021

Aceito: $19 / 07 / 2021$

Publicado: 01/09/2021

\footnotetext{
* Professor of History of Science, Instituto de Historia de la Medicina y de la Ciencia López Piñero, Universitat de Valencia, Spain. orcid.org/0000-0003-4145-9152. E-mail: barona@uv.es.
} 